\title{
A Reformed assessment of George Lindbeck's ecclesial ethics
}

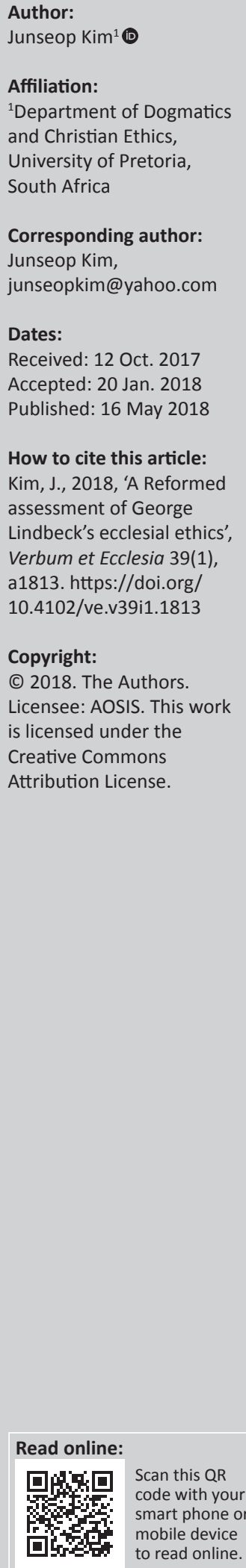

\begin{abstract}
Lindbeck's theology can be defined as an ecclesiology. For the ultimate concern in his life and thoughts is an ecclesiastical one. His ecclesial ethics is based on his ecclesiology. It has two aspects: the intra-systematic view of truth and the cultural-linguistic view of religion. From a Reformed viewpoint, it attempts to overcome theological liberals' universalistic and reductionist tendency by emphasising the particularity of religions. It also focuses on the intratextual and performative aspects of Christian ethics. Its notion of incommensurability, however, has difficulty in explaining the continuity between the world of the Bible and the extrabiblical world, and between religions. In contrast, Reformed theology can solve the problem by using the idea of revelatory continuity.

Intradisciplinary and/or interdisciplinary implication: As a Reformed intradisciplinary assessment on George Lindbeck's ecclesial ethics, this article maintains that his notion of incommensurability finds it difficult to explain the continuity between the world of the Bible and the extrabiblical world, and between religions, and that a Reformed idea of revelatory continuity can be its solution.
\end{abstract}

\section{Introduction}

The contemporary Lutheran theologian George A. Lindbeck (born 1923) has generally been known both as a founder of the Yale school and an advocate of postliberal theology or narrative theology.

Lindbeck's theology can be defined as an ecclesiology. For the ultimate concern in his life and thoughts is an ecclesiastical one. It is substantiated by two kinds of evidence: internal and external evidences. Internal evidence indicates that throughout Lindbeck's life, an ecclesiastical concern has been developing and actively working: his ecclesiastical concern is reflected in all his activities and works. ${ }^{1}$ Internal evidence implies that an ecclesiastical concern has worked as the groundwork of his theology. Eckerstorfer (2004:399) points out that most of the contemporary theologians only focused on Lindbeck's landmark work The Nature of Doctrine (1984) and its heated issues on the interpretation of doctrine. They failed to see its subtitle Religion and Theology in a Postliberal Age. Eckerstorfer (2004:400) argues that their failure was mainly because of their habit of reading The Nature of Doctrine without taking into consideration its extent and context. Eckerstorfer's contention is that a detailed study of Lindbeck's biographical life and theological works would lead us to the recognition that he, in his whole life, had an ardent wish for the realisation of the unified church appropriate for a postmodern age, and, in this respect, his vision has an ecclesiastical character (Eckerstorfer 2004:400).

External evidence indicates that an ecclesiastical concern is at the core of the theological movements in which he has been involved: postliberalism and the Yale school. Firstly, postliberalism has a characteristic feature: it puts an emphasis on the community of faith grounded on, and shaped by, biblical narratives (Placher 1997:344-345). ${ }^{2}$ It means that postliberalism bears in itself an obvious ecclesiastical concern. Then, the Yale school takes interest in how the biblical stories form the identity of the Christian community and its members and shape their understanding of the God

1.For information of Lindbeck's life as an ecumenical, ecclesiastical ecumenical journey, see Lindbeck (2004). Also, for a detailed description of Lindbeck's works, see Eckerstorfer (2001:77-236)

2.Placher (1997:344-345) summarises the characteristics of postliberalism as follows. Firstly, it has a 'non-foundationalist' character; secondly, it does not focus on systematic apologetics, but seeks for 'ad hoc connections' with its surrounding disciplines, such as culture or philosophy; thirdly, it does not attend to the commonalities between religions but to their particularities, or differences. It opposes the theological liberals' argument that all religions are, ultimately, saying the same thing; fourthly, it stresses the importance of the roles of the biblical stories as the basis of the Christians' identification of God and the community of faith, of their understanding of themselves and the world. 
they worship (Placher 1997:344). ${ }^{3}$ It implies that the Yale school places an ecclesiastical concern at its core. In brief, both postliberalism and the Yale school treat ecclesiastical concern seriously.

In summary, the ultimate concern in Lindbeck's life and thoughts is an ecclesiastical concern: the hermeneutical core of his theology is an ecclesiastical concern. In this respect, his theology can be defined as an ecclesiology.

\section{A Reformed assessment on Lindbeck's ecclesial ethics ${ }^{4}$}

Lindbeck's ecclesial ethics based on his ecclesiology has two aspects: the intra-systematic view of truth and the culturallinguistic view of religion.

\section{The intra-systematic view of truth}

Lindbeck's ecclesial ethics opposes theological liberals' universalistic and foundationalist tendency. Instead, it focuses on the unique characteristics of religions. It, also, rejects the scholastic tendency of traditional Protestant theologies. They sought the metaphysical conceptualisation of biblical narratives. In other words, they interpreted biblical narratives through extrabiblical metaphysical frameworks. As a result, biblical narratives are reduced to truth claims and are also transformed into propositional statements. This implies that the Bible is under the authority of extrabiblical rationality. ${ }^{5}$

Lindbeck's ecclesial ethics is based on the rule theory of doctrine, according to which religions are like languages with their own grammars. ${ }^{6}$ For Lindbeck, religions operate as cultural frameworks which produce words and make human experiences possible. The meaning of language is, thus, determined by the use of words in such frameworks. Doctrines function as rules as to how the words can be used, regulating truth claims by removing some and taking others (Lindbeck 1984:19). ${ }^{7}$ For Lindbeck, doctrine itself is not a

3.Placher (1997:344) summarises the characteristics of the Yale school as follows Firstly, it attends to the uniqueness of particular religious traditions; secondly, it focuses on the form and the systems of the Scriptural texts as they are; thirdly, it is concerned with how the Scriptural texts relate to the Christian community.

4.According to Wells (2010:155), ecclesial ethics means Christian ethics that primarily focuses on the life in Christ for the Christian community and does not imply the betterness of, or the mere des says that ecclesial ethics is distinct from universal ethics which focuses on mora values that which emphasises the individual perspective of the peripheral on the other hand. $\mathrm{He}$ also points out that ecclesial ethics tells that in order to discover the true essence of ethics, Christians should focus on the transformation made possible in Christ instead of committing to secular ethics.

5.In his work (1974), Hans Frei, Lindbeck's colleague at Yale, points out that a loss of the narrative character of the Bible has occurred since the Enlightenment in the 17 th and 18th centuries. He says that a great reversal has taken in the interpretation of the Bible: interpretation became an issue of adapting the Scriptural narrative into extrascriptural world based on another narrative instead of fitting the latter into the former (Frei 1974:130).

6.In this respect, Buckley (2002:xi-xiii) regards the rule theory of doctrine, or the cultural-linguistic approach to religion, as 'an extended reflection on analogy'.

7.Pecknold (2005:5-6) says that doctrines are considered to function as rules of the semiotic world of Scripture just like grammars do as rules of other semiotic systems expressed in a community of faith, reflecting the religious customs of its members and subtly influencing first-order religious practices. first-order truth claim; rather, it is a second-order reflection of first-order communal practices. ${ }^{8}$

Doctrine as a second-order reflection implies the performative character of doctrine. For doctrinal assertions can be made only in religious utterances, that is, in aligning himself and the world performatively with what one considers as the most ultimate through religious practices (Lindbeck 1984:69).

Performative doctrine is connected with the intra-systematic and coherent view of truth. The intra-systematic truth opposes the ontological truth, and the coherence theory of truth is in contrast with the correspondence theory of truth. For Lindbeck, religious assertions are true as long as they maintain coherence with the entirety of a related context (Lindbeck 1984:64). ${ }^{9}$

Lindbeck's ecclesial ethics with the intra-systematic view of truth is a performative ethics. It holds that the meaning of religious truth can be found through engagement in religious practices, not in objective realities or religious symbols. Thus, being religious means being familiar with a community-based set of skills that are developed by participation and education (Wells, Quash \& Eklund 2017:203). Also, being a Christian means being accustomed to symbol system of Christianity and at the same time interpreting himself and his experience of the world by using Christian religious terms. ${ }^{10}$

Lindbeck's ecclesial ethics is also connected with ad hoc apologetics which is a postliberal scepticism about extrabiblical foundational apologetics. Ad hoc apologetics claims that a religion, like a language, should be understood only by using its own vocabularies, not by accommodating them into alien concepts (Lindbeck 1984:129). Ad hoc apologetics opposes the extrasystematic apologetics which has the same controlling tendency as post-Cartesian natural theology and the theological liberalism did. Lindbeck takes ancient catechesis as an example of ad hoc apologetics. It did not re-describe Christian faith with extrabiblical concepts but sought to teach communal language and practices of religion to new converts (Lindbeck 1984:132). Lindbeck (1984:132) regards ad hoc apologetics as the essential way through which most religions have been transferring the faith and converting others throughout history. In brief, ad hoc apologetics is towards the inward world of a religious community, not its outward world. It implies that theological

8.Doctrine as a second-order reflection, therefore, cannot be judged to be true or false because they operate just as grammatical rules accepted by a religious community (Gibbs 2015:9). Hinlicky (2010:373) regards these second-order doctrines as having referential neutrality.

9.Lindbeck (1984:64) says that the coherence theory of truth applies to both religious and non-religious domains and that epistemological realists consider the intrasystematic truth to be a necessary, though not sufficient, condition for the ontological truth.

10.Gleason (2016:7) says that through training and participation, adherents of a religion learn to see the world through the cultural-linguistic frame of the religion, and that the frame, in a considerable extent, affects the way they perceive and that the frame, in a considerable extent, affects the way they perceive the world and live in it: although not covering or encapsulating 'a more general, Wells Wells et al. (2017.203-204) say that Lindbeck's performative ethics resembles Aristotle's notion of rationality, according to which rationality is acquired rather than innate. 
ethics should be intra-biblical and intra-ecclesiastical, as the truth is intra-systematic.

Lindbeck's intra-systematic ecclesial ethics has some implications. Firstly, it is an ethics which emphasises the communality of religion. The communality of religion here means that religion functions as a communal linguistic framework that expresses individuals' religious experience. Like culture or language, religion is a communal framework that forms individual identity rather than reveals it. So, his intra-systematic ecclesial ethics opposes the individualisation of religion: it rather emphasises the communality of religion.

Secondly, Lindbeck's intra-systematic ecclesial ethics is an ethics which stresses the concept of intra-textuality. Intra-textuality denotes that meaning is located inside the text. In other words, meaning is by nature 'immanent' (Lindbeck 1984:114). In this respect, Lindbeck's intra-textual ecclesial ethics opposes both the propositional-cognitivist and the experiential-expressivist understanding of religion. For they claim to the extratextual location of meaning. The propositional-cognitivist understanding says that religious meaning is located in the objective realities to which the text refers, while the experiential-expressivist one maintains that religious meaning is located in the experiences which the text symbolises (Lindbeck 1984:114).

Thus, the proper way to determine what 'God' signifies, for example, is by examining how the word operates within a religion and thereby shapes reality and experience rather than by first establishing its propositional or experiential meaning and reinterpreting or reformulating its uses accordingly.

Intra-textuality implies that no world is more real than the one the text creates. Lindbeck says (1984:117) that the world of the Bible can absorb the world we live in, and that the Bible provides believers with the interpretative lens to perceive all reality. For Lindbeck, the Bible can offer non-doctrinal and non-systematic stories through which we comprehend our lives (Hensley 1996:75). Lindbeck (1984:117) argues that the way Christian communities describe extrascriptural realities and experiences is shaped by biblical framework of interpretation much more than is warranted by extrabiblical methodologies. So, he points out the risk of inserting the extrabiblical materials into the biblical world: they will function as 'the interpreter' instead of 'the interpreted' (Lindbeck 1984:118). He argues that the notion of intratextuality is reflected in the Reformers' biblical interpretation. For example, they rejected the allegorising method of exegesis and emphasised 'intra-textuality (scriptura sui ipsius interpres)' (Lindbeck 1984:118). By intra-textuality, the Reformers meant interpreting the Scripture through its usage, that is, through the 'viva vox evangelii' (Lindbeck 1984:118-119).

Therefore, Lindbeck's intra-textual ecclesial ethics says that the members of Christian community should be interpreted by the Bible rather than interpret it. In other words, Lindbeck argues that Christians should interpret themselves and their situations in life by Israel's history and Jesus' stories, not by contemporary extrabiblical concepts, and seek to live according to the biblical teachings. In this respect, Lindbeck's ecclesial ethics is different from theological liberals' attempt to adapt Christianity to modern times.

In conclusion, Lindbeck's intra-systematic ecclesial ethics is an ethics which emphasises the communality and intratextuality of religion.

\section{The cultural-linguistic view of religion}

Lindbeck's cultural-linguistic ecclesial ethics applies to both intra-Christian and interreligious relations.

Regarding intra-Christian relations, Lindbeck's ecclesial ethics seeks intra-Christian unity based on the principle of convergence. Convergence does not mean making a perfectly harmonious agreement, but finding a new set of teaching that breaks mutual contradictions and hence removes the basic causes of the ecclesial divisions (Hinlicky 2010:272). Ecumenical dialogues based on the principle of convergence, therefore, seek to reformulate teaching in such a way that both sides affirm that one's truth claims can be different from the other's (Hinlicky 2010:272). Such reformulations are grounded on the presupposition that there already exist common major doctrines of both sides, such as the beliefs in the God the Trinity and the Christ incarnated as described in the Nicene Creed (Hinlicky 2010:272). The convergence ecumenicity ultimately emphasises the particularity of those participants. It seeks reconciliation without capitulation, which means the rejection of the suppression of each of them over the other caused by doctrinal differences, and at the same time the pursuit of bringing them into the unity of the church (Hinlicky 2010:273). In this respect, mutual respect is demanded for those participants.

Regarding interreligious relations, Lindbeck's ecclesial ethics is based on the notion of incommensurability. By incommensurability, Lindbeck (1984:84) means that vocabularies of a religion cannot be translated equivalently into those of other religions, because there exists the same categorical difference between them as found between quantitative and qualitative expressions of reality.

In this way, incommensurability implies the denial of common religious framework, whether it is of the propositional-cognitivist or of the experiential-expressivist character, within which religions can be compared (Lindbeck 1984:49). Those who support incommensurability thus avoid from the introduction of conceptualities from a religion into those of another one. For they think that the introduced ones would be a simple 'babbling' in new settings: they would function differently from in their original settings (Lindbeck 1984:49). 
An example of an ethics of incommensurability is found in Hauerwas's narrative ethics. For him, stories in a community have the incommensurable, or untranslatable, character. They are the ones which are peculiar to the community. They shape the community, and the community, in turn, preserves them. They cannot be translated equivalently into within the world of another community. In this respect, Hauerwas (1985:11) says that the church should primarily exist as a community shaped by its own stories which the world does not share. In other words, the church should live as a community of virtues grounded on the biblical stories, instead of living by some universal principles based on human rationality (Placher 1997:349). ${ }^{11}$ In short, for Hauerwas, the first ethical task of the church is to be itself.

Hauerwas (1981:85), further, argues that the church should not offer the legitimatising basis for the governing of the nations; it rather should witness to the kind of communitybased on biblical virtues. Instead of providing a principle for political systems, even democracy, the church should be a unique political entity, living the kind of communal life shaped by the story of Christ (Hauerwas 1981:12).

Also, Lindbeck's ecclesial ethics of incommensurability implies anti-reductionism. The virtues from stories of a community cannot be reduced to moral principles of contemporary ethical thoughts. This anti-reductionist character of Lindbeck's ecclesial ethics makes different religions have mutual respect.

In conclusion, Lindbeck's cultural-linguistic ecclesial ethics claims that there should be the virtue of mutual respect in intra-Christian relation, based on the principle of convergence, and in interreligious relation, grounded on the concept of incommensurability.

\section{A Reformed examination of the notion of incommensurability}

Among some problems concerning Lindbeck's ecclesial ethics, the matter of incommensurability has to be critically examined. ${ }^{12}$

The notion of incommensurability can raise a question about the continuity in these two relations: one between the world of the Bible and the extrabiblical world, and one between religions.

Regarding the former relation, incommensurability means that the world of the Bible and the extrabiblical world are

\footnotetext{
11.In this respect, Hauerwas's ethics is called ethics of virtue or ethics of character Particularly, his emphasis on the virtue of peaceableness led him to pacifism. Placher (1997:321) considers pacifism to be the standard form of God's ruling over the world.

12. These problems include the following. It is questionable how Lindbeck's intrasystematic ecclesial ethics, based on the coherence theory of truth, can explain the
origin of the terms in a religious system. In this regard, McGrath (1990:28) raises a question: if doctrine is related with the use of language of the Christian idiom, how question: if doctrine is related with the use of language of the Christian idiom, how
could this language come into existence, and what, if anything, is its referent could this language come into existence, and what, if anything, is its referent
object? In addition, it is doubtful whether the cultural-linguistic approach to object? In addition, it is doubtful whether the cultural-linguistic approach to
religion could be properly applied to interreligious relations of Eastern religions, such as Buddhism or Confucianism. For Lindbeck has mainly applied it to such as Buddhism or Confucianism. For Lindbeck has mainly applied it to
interreligious relations of Western religions which, in particular, have similar interreligious relations of Western religions which, in parti
religious traditions, such as Christianity, Judaism and Islam.
}

mutually untranslatable. In this respect, it implies the discontinuity between those two worlds. In particular, any claim to the discontinuity between the world of the Bible and the contemporary world of civilisation or technology would be controversial. Regarding the latter relation, incommensurability denotes that the characteristics of a religion are untranslatable and irreducible.

The problem is whether the belief in incommensurability is justifiable. McGrath (1990:87) points out that cultural incommensurability may lead to a quantal approach to history which regards history as comprising 'discrete cultural totalities', whose part is untranslatable into 'its diachronic and synchronic neighbours'. He argues that such a belief is not empirical but just dogmatic because of its disregarding the reality of cultural development (McGrath 1990:87). He emphasises cultural development through a cumulative process, which means the continuity between the past and the present (McGrath 1990:86). ${ }^{13}$ For him, the belief in cultural incommensurability, especially in extreme cultural incommensurability, is neither justifiable nor defensible. So, Lindbeck's ecclesial ethics must avoid from any belief in extreme incommensurability. Otherwise, it cannot help being charged with theological sectarianism or fideism. ${ }^{14}$

Reformed notion of revelation can be a solution to the discontinuity between the world of the Bible and the extrabiblical world, and between religions.

The starting point of Reformed ethics is God's revelation (Van Keulen 2010:34). In Reformed theology, God's revelation is generally distinguished in two ways: the general revelation and the special revelation.

Regarding the continuity between the world of the Bible and the extrabiblical world, Reformed theology can approach it from a revelatory perspective. Reformed theology understands God's creation and providence as God's revelation. Bavinck (2003:307) considers the creation to be God's first revelation, the start of and the basis for all the following revelations. God first revealed himself outwardly through the creation (Bavinck 2003:307). The event of creation is immediately followed by God's action of providence (Bavinck 2003:307). God's providence encompasses the entirety of the created world (Helseth 2011:29). Reformed theology holds that God's providence operates through preservation, concurrence and government, which are always organically and integrally connected (Helseth 2011:31). In brief, the whole world which was created by God and is under his providence, in a Reformed view, is understood as God's revelation.

\footnotetext{
13.Regarding the continuity, McGrath $(1990: 87-88)$ says that it has been evidenced by many important findings, for example, the finding of the continuity between the cultures of the early church and the modern one, and that such findings are the products of both the 'informed empathetic imagination' and ' $t$ the selective appropriation of the past' as strategies for diminishing the strangeness of the past.

14.Lindbeck's ecclesiology implies sectarianism of a sociological rather than theological sense, in that it emphasises that the church should pursue a different life from the one requested by a given society (Fergusson 2004:36). In this respect, Lindbeck (1984:78) occasionally considers his ecclesiastical position as 'sociological sectarianism'. Lindbeck (1984:130-132) also argues that the notions of intratextuality and postliberal anti-foundationalism do not imply fideism or relativism.
} 
Reformed theology also considers the Bible as God's revelation, precisely God's special revelation. Bavinck (2003:385) says that the Bible is rooted in the past and is at the same time the product of God's revelation in the history of Israel and in Christ. It is, nevertheless, not simply an old anecdote or a book of ancient chronicle but the eternal and living Word, through which God speaks to his people (Bavinck 2003:385). In this respect, Bavinck (2003:385) describes the Scripture as 'the living voice of God'.

In brief, Reformed theology understands that both the Bible and God's creation and providence belong to God's revelation. Thus, in a Reformed view, there exists a revelatory continuity between the world of the Bible and the extrabiblical world. ${ }^{15}$ In this way, Reformed theology can solve the problem of Lindbeck's notion of incommensurability: it has difficulty in explaining the continuity between those two worlds.

Regarding the continuity between religions, Reformed theology can also approach it from a revelatory perspective. It considers all religions as the bearers of the general revelation. ${ }^{16}$ In this respect, religions, in a Reformed view, have a revelatory continuity. Thus, Reformed theology can provide a way to explain the continuity between religions, while Lindbeck's notion of incommensurability has difficulty in doing so.

\section{Conclusion}

From a Reformed viewpoint, Lindbeck's ecclesial ethics is assessed as follows. Regarding its challenging aspects, firstly, Lindbeck's ecclesial ethics is an attempt to overcome theological liberals' reductionist tendency by emphasising the particularity and the differences of religions. Secondly, it emphasises the intra-textual and performative aspects of Christian ethics. Thirdly, it seeks to establish the interreligious relations appropriate for our age. We, nevertheless, can find that it has a weakness: its notion of incommensurability has difficulty in explaining the continuity between the world of the Bible and the extrabiblical world, and between religions. In contrast, Reformed theology can solve the problem by using the idea of revelatory continuity.

15.Also there exists a revelatory difference between them, in that the world of the Bible is connected with the Bible as God's special revelation, and the extrabiblical world is connected with God's creation and providence as God's general revelation. In this respect, each of these two worlds has its own revelatory particularity.

16.Calvin (1960:44) believes that a seed of religion, the knowledge of the existence of God, is implanted in all human beings. Kim (2003:16) argues that all religions affirm the general revelation of God, referring to the transcendent being and fostering pious religiosity and morality. Kim (2003:15-16) says that the general revelation of God may be a groundwork for Reformed theology's engagement in interreligious dialogues.

\section{Acknowledgements Competing interests}

The author declares that he has no financial or personal relationships which may have inappropriately influenced him in writing this article.

\section{References}

Bavinck, H., 2003, Reformed dogmatics, J. Bolt (ed.), transl. J. Vriend, Baker Academic, Grand Rapids, MI.

Buckley, J.J., 2002, 'Introduction: Radical traditions: Evangelical, catholic and postliberal', in G.A. Lindbeck \& J.J. Buckley (eds.), The Church in a postliberal age, pp. vii-xviii, SCM Press, London.

Calvin, J., 1960, Institutes of the Christian religion, vol. 1, J.T. McNeill (ed.), transl. F. L. Battles, Westminster Press, Philadelphia, PA.

Eckerstorfer, B.A. OSB, 2001, Kirche in der Postmodernen Welt: Der Beitrag George Lindbecks zu Einer Neuen Verhältnisbestimmung, Tyrolia Verlaganstalt, Wien.

Eckerstorfer, B.A. OSB, 2004, 'The one church in the postmodern world: Reflections on the life and thought of George Lindbeck', Pro Ecclesia 8(4), 399-423.

Fergusson, D., 2004, Community, liberalism and Christian ethics, Cambridge University Press, Cambridge.

Frei, H.W., 1974, The eclipse of biblical narrative: A study in eighteenth and nineteenth century hermeneutics, Yale University Press, New Haven, CT.

Gibbs, J., 2015, Apologetics after Lindbeck: Faith, reason, and the cultural-linguistic turn, Pickwick Publications, Eugene, OR.

Gleason, P., 2016, 'From Jürgen Habermas to George Lindbeck: On translating religious concepts into secular terms', The Journal of Scriptural Reasoning 15(1), 1-12.

Hauerwas, S., 1981, A community of character: Toward a constructive Christian social ethic, University of Notre Dame Press, Notre Dame.

Hauerwas, S., 1985, Against the Nations: War and survival in a liberal society, Winston Press, Minneapolis, MN.

Helseth, P.K., 2011, 'God causes all things', in P.K. Helseth, et al. (eds.), Four views on divine providence, S.N. Gundry, et al. (eds.), pp. 25-52, Zondervan, Grand Rapids, MI.

Hensley, J., 1996, 'Are postliberals necessarily antirealists?: Reexamining the metaphysics of Lindbeck's postliberal theology', in T.R. Phillips \& D.L. Okholm (eds.), The nature of confession: Evangelicals \& postliberals in conversation, pp. 69-80, InterVarsity Press, Downers Grove, IL.

Hinlicky, P.R., 2010, Luther and the beloved community: A path for Christian theology after Christendom, William B. Eerdmans, Grand Rapids, MI.

Kim, Y.H., 2003, 'The identity of reformed theology and its ecumenicity in the twentyfirst century: Reformed theology as transformational cultural theology', in W.M. Alston \& M. Welker (eds.), Reformed theology: Identity and ecumenicity, pp. 3-19, William B. Eerdmans, Grand Rapids, MI.

Lindbeck, G.A., 1984, The nature of doctrine: Religion and theology in a postlibera age, SPCK, London.

Lindbeck, G.A., 2004, 'Paris, Rome, Jerusalem: An ecumenical journey', Journal of Ecumenical Studies 41(3-4), 389-408.

McGrath, A.E., 1990, The genesis of doctrine: A study in the foundations of doctrinal criticism, Blackwell, Oxford.

Pecknold, C.C., 2005, Transforming postliberal theology: George lindbeck, pragmatism and scripture, T\&T Clark, New York.

Placher, W.C., 1997, 'Postliberal theology', in D.F. Ford (ed.), The modern theologians: An introduction to Christian theology in the twentieth century, 2nd edn., pp. 343-356, Blackwell, Oxford.

Van Keulen, D., 2010, 'Herman Bavinck's Reformed Ethics: Some remarks about unpublished manuscripts in the libraries of Amsterdam and Kampen', The Bavinck Review 1, 25-56.

Wells, S., 2010, Christian ethics: An introductory reader, Blackwell, Malden, MA.

Wells, S., Quash, B. \& Eklund, R., 2017, Introducing Christian ethics, 2nd edn., Wiley-Blackwell, Hoboken, NJ. 